\begin{tabular}{|l|l|l||}
\hline \multicolumn{2}{|c|}{ PublisherInfo } \\
\hline \hline PublisherName & $:$ & BioMed Central \\
\hline \hline PublisherLocation & $:$ & London \\
\hline \hline PublisherImprintName & $:$ & BioMed Central \\
\hline \hline
\end{tabular}

\title{
Shocking phosphorylation of histones
}

\begin{tabular}{||l|l|l||}
\hline \multicolumn{2}{|c||}{ ArticleInfo } \\
\hline \hline ArticleID & $:$ & 3946 \\
\hline \hline ArticleDOI & $:$ & $10.1186 /$ gb-spotlight-20010104-01 \\
\hline \hline ArticleCitationID & $:$ & spotlight-20010104-01 \\
\hline \hline ArticleSequenceNumber & $:$ & 17 \\
\hline \hline ArticleCategory & $:$ & Research news \\
\hline \hline ArticleFirstPage & $:$ & 1 \\
\hline \hline ArticleLastPage & $:$ & 2 \\
\hline \hline & $:$ & RegistrationDate : 2001-01-04 \\
ArticleHistory & $:$ & OnlineDate $: 2001-01-04$ \\
\hline \hline ArticleCopyright & $:$ & BioMed Central Ltd2001 \\
\hline \hline ArticleGrants & $:$ & \\
\hline \hline ArticleContext & $:$ & 130592211 \\
\hline \hline
\end{tabular}




\section{Jonathan Weitzman}

Email: jonathanweitzman@hotmail.com

Histone modifications are required to gain access to DNA sequences within the tightly compacted genome and enable gene transcription. It has been proposed that acetylation of the amino-terminal tails of the core histones within the nucleosome particle is critical for activating transcription. In the December Genes and Development, Nowak and Corces suggest that histone phosphorylation may play a greater role than acetylation in gene induction (Genes Dev 2000, 14:3003-3013). They studied the heat shock response in Drosophila melanogaster and the role of histone modification using immunocytochemical analysis of polytene chromosomes. Heat shock causes a general repression of gene expression and a rapid induction of specific heat shock genes. Acetylation of core histones $\mathrm{H} 3$ and $\mathrm{H} 4$ did not change during the heat shock response. In contrast, antibodiesrecognizing phosphorylated histone $\mathrm{H} 3$ tails revealed dramatic changes in phosphorylation associated with the transcriptional response to heat shock.

\section{References}

1. The language of covalent histone modifications.

2. Genes and Development, [http://www.genesdev.org]

3. Mitosis-specific phosphorylation of histone $\mathrm{H} 3$ initiates primarily within pericentromeric heterochromatin during G2 and spreads in an ordered fashion coincident with mitotic chromosome condensation. 